\title{
The Discourse of Submissiveness to God in the Pandemic Time through "BURDAH KELILING"
}

\author{
Mundi Rahayu ${ }^{1}$, Mediyansyah ${ }^{2}$ \\ ${ }^{1,2}$ UIN Maulana Malik Ibrahim Malang \\ ${ }^{1}$ mundi@bsi.uin-malang.ac.id, ${ }^{2}$ mediansyahtaharani@yahoo.co.id
}

\begin{abstract}
"Burdah Keliling" is an activity in which people of a village walking around the village, led by an ustad or kyai (local religious teacher) while chanting "Sholawat Burdah". Shalawat burdah is one of shalawat or singing praising Muhammad SAW which is very popular among Indonesian muslim community especially in the rural areas. The lyrics or material of shalawat is religious and the texts are devotional. This paper aims at explaining the discourse of Burdah Keliling as a cultural approach of mitigation of the pandemic Covid-19. The specific question raised in this paper: how is the discourse of submissiveness to God represented through "Burdah Keliling." This is a qualitative method, using observation, and online interview. The observation takes the online news media, and online interview aims to reveal the experience and opinion of the persons involved in the activity of Burdah Keliling. The writers argue that the cultural activity of Burdah keliling has played important roles in building people's well-being psychologically. In the pandemic time nowadays, people need an activity that nurture them psychologically so that they can avoid stress and pressure due to the pandemic. The analysis is done through Fairclough's Critical Discourse Analysis. The study shows that "burdah keliling" is very meaningful for the people involved in the activity. This activity means to express people's submissiveness, surrender to Allah SWT, so that avoiding them from panic and stress due to the pandemic of covid-19 rampaging across the country.
\end{abstract}

Keywords

Burdah keliling, Covid-19, resilience, pandemic, Shalawat Burdah

Article Received: 10 August 2020, Revised: 25 October 2020, Accepted: 18 November 2020

\section{Introduction}

The realities of pandemic Covid-19 rampaging across the country has been a big problem. From the first case announced by President Joko Widodo, 2 March 2020, until today, there have been more than 240.000 cases of people infected by the virus Covid-19 spread out to all of provinces, cities, regencies, and villages in Indonesia (Kompas.com, 20 September 2020). The graphic that is increasing day by day makes people more tensed and stressed. Some other people wonder why the number is increasing. Some other people are afraid of seeing the increasing number and prefer not to see the number. Government has taken many strategies of curbing the pandemic, by establishing the task force of covid-19 from the central government level, provincial, up to village levels. There is a criticism on the managing the issues of virus and pandemic which so far has been hegemonized by and reduced into the problem of medical issues (Irwan Abdullah, 2020). Therefore, from many strategies to reduce the escalating number of cases there is an important aspect that need more attention, that is the cultural approach.

The importance of cultural approach in mitigating the pandemic in Indonesia has been responded by Universitas Gadjah Mada through some sociocultural studies on the pandemic Covid-19 (Suwignyo, 2020). Under the sociocultural perspective, pandemic is related to cultural knowledge. People's cultural knowledge has played important roles in facing the pandemic. Through the cultural knowledge that the community has developed, people can deal or mitigate the impact of the pandemic. One of the cultural knowledge discussed in this paper is the practice of chanting shalawat burdah while walking around the kampung, which is commonly called burdah keliling.

Many studies on Shalawat burdah has been done by many historians in Indonesian and other countries. Eko Setyawan (2017) wrote the article "Nilai-nilai Relijius dalam Shalawat Burdah" discussing the poetic expression in the lyrics of Shalawat burdah which was written by Imam Bushiri. The lyrical poems were aimed at praising 
the prophet Muhammad SAW. The lyrical poem contains moral values such as the notions of repentance, zuhud (very simple of life), patience, sincere, tawakkal, and mahabbah. Those values are one of important aspects that make shalawat Burdah popular among Muslim around the world. For Muslim, praising the prophet Muhammad SAW is a necessary ritual to do, and some other people consider it as the most important one. Muslim believe that praising the prophet will bring many virtues, in the world and after the world, and their "doa" (pray) will be fulfilled with the help of the prophet (Setyawan, 2017).

Another research on Burdah was done by Manshur (2006), highlighting the reception of Qasidah Burdah Al-Bûshîry among pesantren communities. In the article, Manshur wrote that Qasidah burdah is a religious literary work that has been widely appreciated and obtained positive reception around the world. The qasidah burdah has been translated into many languages around the world, such as English, French, Spain, Italy, Dutch, and German. It was also translated into Nordic languages: Norway, Sweden, Denmark, Islandic, and Finlandia. In eastern part of the world, the qasidah was translated into Russian, Turk, Persian, Urdu, Chinese, Swahili, Indonesia and local languages in Nusantara such as Sunda, Javanese, and Aceh (Manshur, 2006).

The present article explores the empirical study on "Burdah keliling" as a cultural knowledge for Muslim community in dealing with pandemic. Burdah keliling was done by people in a village at night in the pandemic time. The activity of "burdah keliling" is led by the ustad started from the mosque at the village, followed by young people. This tradition is popular among the traditional Muslim, like that happened in East Java villages. In my observation on the online news about burdah keliling, it was practiced by people at villages in Madura, and other regencies in East Java like Banyuwangi, Situbondo, Jember, Surabaya, Gresik, and others. I also found out that Burdah keliling was performed by Muslim in South Kalimantan and West Kalimantan (JatimPos.Co. 31 Maret 2020, Beritabaru.co. 17/04/2020, Antara Jatim 19 Maret 2020). This paper aims at explaining the discourse of people's submissiveness to God in pandemic time, represented in Burdah keliling.
The writers argue that the practice of Burdah keliling has socio-psychological aspect that gives impact to the perpetrator of the burdah. This was due to the fact that people chanted, "shalawat" praising to Rasulullah SAW, along the lyrics of the shalawat burdah. This religious lyrics have spiritual aspect that makes people feeling close to the God, especially in the long pandemic time which brings about frustration and depression among the society. So, the chanting of shalawat burdah helped people to go through the difficult time. In addition, in its historical aspect, shalawat burdah was created as a means for healing the author's illness, so that there is a tradition of making it as a means of medication.

\section{Method}

The paper is written based on a qualitative research. The qualitative research is the kind of research that highlight to the depth of data exploration (Grant. A, 2019). The data, in the form of verbatim text, were collected through observation, interview, and documentary study. Observation to the activities of Burdah keliling in many places in East Java was done through the online news and local portal, like JatimPos.Co. (31 Maret 2020), Beritabaru.co. (17 April 2020), Antara Jatim 19 Maret 2020), and through narration from informants involved in the activity. Interview was done with some people that is conducted via social media and online communication. Thedata was taken during the pandemic Covid-19 (May-July 2020). The key informant is a personfrom Sampang regency that join the Burdah keliling in his village, whose relatives is the local preacher (religious teacher) in the village who lead the Burdah keliling. The other informant comes from Sumenep, whose brother is a teacher of madrasah who used to be a local religious teacher and attended the burdah keliling in his village.

Documentary study (Grant, A., 2019) was done through reading the text of online news on Burdah keliling, some of them are: "Antara Jatim.com, JatimPos.co, Beritabaru.co." The researcher also made documentary study on the text of shalawat burdah in Arabic language and its translation in bahasa Indonesia that can be found out from the internet (www.laduni.id), and listening to the 
shalawat burdah in youtube (uploaded by Azka Chelsea).

The analysis is done by applying Fairclough's Critical Discourse Analysis. The Critical Discourse Analysis (CDA) proposes the analysis of a textual discourse by comparing, interpreting, and synthesizing data(Fairclough, 1989). The CDA is considered appropriate for this study because of its nature to explore on the discourse, as stated in the research question of this paper. In addition, it uses CDA because of the fact that the phenomena of burdah keliling as the tool for mitigating pandemic is considered as marginalized. So that the application of CDA is intended to find out the discourse implied in the practice burdah keliling. Fairclough's CDA is based on three levels of analysis, in which the first level covers micro level, with analysis related to language phenomenon such as wording, metaphor, and syntax. Second, meso level, the analysis is related to the production and consumption of the text. At macro level, the analysis examines sociopolitical context of the text. In discussing the "Burdah Keliling," the focus was upon the discourse of submissiveness of God in the pandemic.

\section{Literary Review}

\section{Shalawat Burdah, A Historical Perspective of Lyrical Poem}

Historically, shalawat burdah is rooted back to the long poem written by a popular poet Imam Al Bushiri in the 13th Century Egypt. Shalawat Burdah is also popularly called Qasidah Burdah is a lyrical poems or in Arabic term called Qasidah. It was the literary work of Syarafuddin Abu Abdillah Muhammad bin Zaid Al-Bushiri (610695H/1213-1296M), born in Dallas Maroko, and grew up at Bhusir, Egypt.That is why he is popularly called Al Bushiri, a Sufi and poet. Qasidah Burdah is a long poem containing the praise (shalawat)for Muhammad SAW. The lyrics was written at the time of transition of Ayyubid dynasty to Mamluks Dynasty (Adib, 2009).

It was popularly told that Imam Al-bushiri at that time suffered from paralysis in a long time. He had consulted to his guru, and he was told to write down lyrical poems. Then he wrote down the poem, a long lyrical poem praising to the
Rasulullah, Muhammad SAW. For Al Bushiri, the qasidah is a literary work, and at the same time functioned as a medium for praying to the God, Allah SWT to get medication for his illness. This work was then called Qasidah burdah, which is the master piece of Imam Al Bushiri (Mashur, 2006).

Burdah in Arabic means coat. It was told that when Imam Al Bushiri was suffered from his illness, he prayed to God and he prayed through his long lyrical poem. One night in his dream, he was visited by Muhammad SAW, and the prophet covered his burdah (coat) to his body. Surprising with his dream, Al Bushiri woke up immediately and he was even more surprised because he was able to move and he was recovered. Because of this story, the lyrical poem is popularly known as Qasidah burdah. The miracle that happened to Imam Bushiri built a discourse since then, that the lyrical poem brings miracle, especially for abolishing and removing any illness in a community and other harmful incidents or disaster in a community. This miraculous poem is believed by many Islamic community in many parts of the world (Adib, 2009).

The popularity of Qasidah Burdah had reached many parts of the world where Muslim people live. It has been reaching many centuries up to now (Nasr, 1994; Glasse, 1996). Many Muslim around the world have studied the qasidah and practiced it. The popularity of the Qasidah Burdah is supported by the strong belief among Muslim that praising the prophet is the excellent virtue that is very good for their life in this world and world-after. Muslim believe that shalawat make them obtaining syafaat or help from the prophet, a help that ranging from the problems in the world and in the world-after. That is why shalawat, especially shalawat burdah is popular and believed to be having religious power (Mashur, 2006).

Qasidah burdah is not only considered as beautiful literary work, but its prophetic power dominates its existence (Hitti, 2005:883). Since it was created by Al Bushiri, qasidah Burdah has got the position as lyrical poems that have "supranatural" power. Many people use the qasidah as "mantra" (spell) for recovering from illness (as the case with the Al Bushiri himself), for avoiding bad 
luck, disaster, and other bad deeds from enemies, or as a praying in the funeral ceremony.

\section{Shalawat Burdah as Poetic and Prophetic Lyrics}

Shalawat or qasidah Burdah is one of the most popular lyrical poems, compared to the other lyrical poems. It is called as the pioneer in the qasidah of praise to the prophet Muhammad SAW. It was considered as pioneer because it was written in 13th century, after the lag of lyrical creation of praise to the Prophet, in a long time. After the creation of this qasidah many other lyrical poems for praising the Rasulullah SAW created. At first, the qasidah Burdah written by Imam Bushiri was entitled "alkawakib al-durriyah fi madh khayr albariyyah" (glowing stars for praising the best creature in the world), but then it is popularly known as Qasidah Burdah (Adib, 2009).

The lyrical poems of qasidah Burdah has poetical richness in the Arabic literature, with the pattern of poetical devices for praising the prophet Muhammad SAW (Adib, 2009). The praise that is full of love and respect to the God's love. The diction and rhymes make it easily memorable. In many recording of the qasidah burdah, the lyrics can be sung in various songs. For the creator, Imam Bushiri, the qasidah has played important roles. Bushiri was also a sufi, the follower of tarekat sadziliyah, a tarekat established by Syekh Abu Hasan asy-Syadzili (Glasse, 1996). As a sufi, Al Bushiri has strong motives to love and longing for the prophet. All of the expression of love he created through the lyrics is aimed at praising and loving the Prophet Muhammad SAW. The shalawat is not other than ideology of loving the prophet. This ideology laid the foundation of all the expression of love in the lyrical poems. For this reason, the lyrical poems like Qasidah burdah has a strong influence among the Sufi communities, who love to spend the whole life to praise the prophet (Glasse 1996).

Shalawat burdah consists of 160stanzas. The lyrics in the stanzas consist of ten themes (1) The prologue of love for the loved one, 12 stanzas, (2) The warning on the danger of following the desires, 16 stanzas (3) praising the prophet, 30 stanzas (4) the story of the birth of the prophet, 13 stanzas (5) Miracles, 16 stanzas (6) Al-Quran, 17 stanzas (7) Isra Miraj, 13 stanzas (8) Jihad, 12 stanzas (9) closingand apology 12 stanzas or some other scholar said, 19 stanzas (Setiawan, 2017). One of special features of the lyrical poems of Qasidah burdah is that though it is long poems, the words are relatively easily remembered and articulated.

\section{Result and Discussion}

\section{Shalawat Burdah in Indonesia}

The tradition of reading or chanting shalawat Burdah is closely related to the process of Islamization in Nusantara that involved the pesantren and tariqot (sufi community. In many pesantren, qasidah or shalawat is taught and included in the curriculum of pesantren as part of the learning classical books and part of the teaching learning process in pesantren. The tradition is popularly known in pesantren in Sunda, West Java which is done by learning the book in the form of written book, oral teaching, recordedform, or performing art (Dhofier, 1982; Manshur, 2006). Reading and learning the lyrical poems of qasidah burdah, most of the santri get understanding on the text of the lyrical poems, even it is at the literal meaning. At least they understand what is the qasidah burdah historically, and some reasons why people practice qasidah burdah.

Shalawat burdah is popularly practiced, and sung in many occasions such as Maulid, and the important days or holy days. Moreover, there is a belief that reading "shalawat" is a practice that has significant virtues and gives many advantages, both aesthetic and prophetic or spiritual values. The spiritual values here mean that the praying will be fulfilled by God, and the more important thing is that obtaining syafaat or help from Rasulullah (Hadi, 1997). The tradition developed in the pesantren environment is then spread among the society in which the santri (students) return to home after the study. Most of the santri returns homes to their home village as an ustadz (religious teacher), teaching the religion at the mosque or as "kyai kampung."So, the tradition inside pesantren was developed in the community because of the roles and agency of the santri who 
become religious leader at their home kampung (source: the informant 1).

Qasidah burdah is believed to have many functions, such as tradition in celebrating important moments or religious events. It also functions as a means of praying to God, Allah SWT to be saved from any disaster and diseases. In other word it functions as a guard to keep people well-being. The lyrics is a prayer and praise to Rasulullah SAW in the hope to get syafaat, the help from Rasulullah SAW. It is believed that though the Prophet Muhammad SAW died in 6 Century, that means 13 centuries ago, he is still accompanying the Muslim people and would listen to the people who pray for him. That is why practicing or chanting the Qasidah Burdah is meant to expect the miracle or help from the Prophet. People hope that the Prophet will help them to recover from pandemic, diseases, saved from the wild animals, from burglar, robber, and other disaster (source: informant 1, 2, 3).

The tradition of Burdah keliling is another form of practicing shalawat. Burdah refers to shalawat burdah, while keliling (Indonesian language) means walking around the kampung or village. This tradition is practiced by many traditional Muslim group at many areas in Indonesia, such as Banyuwangi, Bondowoso, Situbondo, Jember, Madura, Surabaya, and other places like South Kalimantan, and East Kalimantan (JatimPos.co; Antara Jatim.com). Burdah keliling is commonly practiced to celebrate the Mawlid, and New year of Hijra, as the prayer to reject bad things, and avoid other disasters such as pandemic.

\section{The Discourse of Submissiveness to God in Pandemic times}

The lyrics of shalawat burdah are dominated by the expression of praise to the Prophet, Muhammad SAW. Through praising the prophet, Muslim show their love, respect, and praise to the most loved people. Through reciting shalawat, people expect that they are heard by the prophet and in doing so, their "doa" are heard by the God. Muslim believe that whatever they want, they just have to pray to God, asking for God's mercy (source: informant 2).
In the pandemic time, people living in rural areas do not have access to the sophisticated health facilities. They know and heard about pandemic from the television and the village administration. Most of young people knew the information of covid-19 through social media. "In my village there is no any positive cases of Covid-19. I know the positive cases of Covid-19 of neighboring village at district (kecamatan). Maybe those allegedly positive of Covid-19 were coming from cities (Surabaya, Jakarta or from Malaysia). Or, those returned home because there was no job in the cities" (informant 1 ).

The daily information that people heard from the television and newspaper, that the number of infected by Covid-19 was increasing day by day. Many people from cities returned home, students also stayed at home and doing the schooling from home. This situation made the pandemic increasingly affected people's life. The health protocols that people have to wear masks, wash hands, and keep distance, were not easy to be implemented. In the villages in Sampang, for instance, many people did not obey the protocols because there were no cases of infection in their neighborhood. The important response to the pandemic was doing communally was practicing "burdah keliling." They chanted shalawat burdah, from the starting point in the local mosque, led by the local religious teacher. The burdah keliling was done at night, after Isya prayer, people, especially young men and children together chanted shalawat burdah while walking around their village. Walking around the kampung or village is meant as protecting the whole village through the shalat burdah. In doing so, they were submitting to God, asking for God's mercy to protect them from the pandemic.

The religious teacher explained to the people that shalawat burdah is a "prayer" to ask for God's favor, God's mercy to protect them from the disease or pandemic. This was rooted from historical story that in the past time, there was a pandemic called thaun, and the shalawat burdah was practiced to submit to God, to ask for God's mercy and protection. This idea was installed among the Muslim, so that many Muslim practiced the burdah keliling especially in the pandemic time, or in the beginning of new year, and in many other critical situations. This can be 
seen from what the informants said, that Burdah Keliling was usually done when the village or community has critical situation. For example, historically burdah was practice when there was "thaun" (plague) in the past, and in other critical situation such as disease or burglar or bad people attacked their village (source: informant 1 )

People's submissiveness to Allah SWT in the case of pandemic could be seen, through people's saying that "when they experienced a critical situation, and people did not feel any other help that solve the crises, they only have the God, Allah SWT." For that reason, the ritual like doing burdah keliling functioned as the means of asking for Allah SWT's mercy and help to overcome the difficult situation. Based on the observation and interview, people do this at the beginning of the pandemic, around early April. In Indonesia, the beginning of covid-19 was March, and it happened in metropolitan Jakarta. At the early next month, people at the rural areas far from Jakarta have been alert with the pandemic. Some cases of Covid-19 at the rural areas had been detected. For example, in East Java, from the cluster of "wisma haji" was soon spread to other rural areas surrounding East Java. The panic and confusion of people with minimum knowledge of the virus, was then responded by local religious teachers to do the activities that make them closer to Allah, to be more submissive to Allah, like chanting the shalawat burdah and Burdah keliling.

From the observation of the practice of Burdah keliling, it can be concluded that this activity played important roles in dealing with pandemic Covid-19, such as religious and social psychological roles, The religious roles means that doing the activity of burdah keliling is a religious activity, based on the belief to Allah SWT, and the Prophet. This activity is a religious in the form of its leader, religious teacher and it is attended by religious group. People believe that chanting shalawat burdah is according the right guidance of praise the Prophet. Praying and chanting shalawat are religious actions that have been instilled in their belief. This belief makes them calm down, avoid the stress and social panic due to the fastspreader virus of Covid-19. The belief that shalawat burdah is able to avoid stress is important, without mentioning whether or not they understand the meaning of the lyric of shalawat Burdah.

Most of the people (male, young) joining the "Burdah keliling," did not really understand the meaning of the lyric or the history of the shalawat burdah. They only followed the ustad or kyai who lead the procession of burdah keliling. Only those who learnt in pesantren understand the lyric or the history of the qasidah burdah. The procession of Burdah keliling started after they finish Isya prayer, at mosque, then lead by the ustad or kyai, they brought torches at hands and walking while chanting the shalawat burdah. They started at the mosque, with the ustad in front of them reading the shalawat burdah, together they walked around and back to the mosque. The leader (ustad) would read the shalawat burdah in more complete at the end, as the prayer.

Most people constructed the perception that the shalawat burdah keliling was a ritual to pray, asking for the God's mercy to demolish the virus or pandemic. The praying together by chanting shalawat burdah was metaphorically called "mengetuk pintu langit" (knocking the door of the sky), as said by the group of young people of Ansor who practiced Shalawat burdah keliling (Beritabaru.co. 17/04/2020). The God was assumed to stay at the kingdom in the sky, so that people asked for God's mercy by knocking the door in the sky together. The more people knock the door, the more effective it is. The goal would be met soon. This metaphor meant that praying together with many people would be more effective to persuade Allah to grant His mercy.

At Bangkalan, many people perceive the shalawat burdah as a praying that they called it "Burdeh,"and people just understood it as a ritual to expel the pandemic or "taun" disease. The shalawat read by ustad or local religious leader(kyai kampung), which was in Arabic language, understood as prayer, so that the other people say "Amiin" at the end of the stanzas. People believed at the ustad or religious leader. Most people did not use the Arabic language actively. People did not understand the Arabic language, but they read the prayer in Arabic everyday or able to memorize the verses of Quran, without guaranteeing that they understood the meaning of the verses. 
At Prajjan village, Calong, Sampang, for example, people uploaded the Burdah keliling at youtube (April 2020), the group of young people practiced Burdah Keliling. They walked from the mosque (after Isya prayer) around the kampung, passing small street, led by the ustad (male). Most of the participants of the burdah keliling were male young people and some were children. There was no girl seen in the group. They walked with the torches at hand, because most of the street were dark, no street lamps. While walking they chanted the chorus "maula ya shalli wa salim da iman abada..." Only the leader read the long stanzas of the shalawat burdah, though not finishing all of the 160 stanzas. At the other villages, in Sampang, burdah keliling was done at the end of March and beginning of April, done for several times, especially at the Friday eve.

At Batang-batang, Sumenep, some villages have had the Qasidah Burdah or Burdah keliling, especially every Friday eve, because it was considered as sayyidul ayyam. The main goal of practicing Qasidah burdah was expecting the syafaat of Rasulullah. They believe that chanting the shalawat burdah, made their prayer granted by Allah, and their family, themselves, and neighborhood were saved from any diseases or disaster, like "taun," jinn possessed, fire, and others. About the end of March, 2020, some kampung practiced the burdah keliling, when the news on pandemic was incessant that made people depressed. At Krampon, for instance, burdah keliling was done once at beginning of April, while at the neighbor kampung, the Burdah keliling was conducted twice or three times (informant, 2020).

Most of Maduranese Muslim shared the similar perception that shalawat was a kind of "obligatory" though there was none say it obligatory, but it was suggested by the ustad or kyai at the religious teaching (pengajian). For that reason, the general perception said that practicing / reading shalawat was a good deed. There was popular expression among Madurese "Abantal Shadat, apajung Allah, asapo salawat" (Syahadat as the pillow, Allah as the umbrella, Salawat as the blanket). This expression was from the poem written by KH D. Zawawi Imron, a very popular poet respected by Madurese. In his first poem collection "Bantalku Ombak, selimutku Angin" (published 1996), there was a phrase "abantal ombak, asapok angen, apajung Gusti Allah," the expression to described the life of fishermen who was in full risk, in daily life when they were at sea. The risk of losing the life was clearly in front of their eyes. So, among the high waves and storm, they were submissive to the God, to Allah SWT. The total submissiveness was expressed through the words of "abantal syahadat, asapo' shalawat Nabi saw, apajung gusti Allah" meaning total submissiveness to the God, expecting the prophet's syafaat and the help of Allah SWT.

Not only at rural areas, the Burdah keliling was also practiced at Surabaya in the pandemic time, by the executive members of GP Ansor Jawa Timur dan Majelis Burdah Selimut Kerinduan along with hundred people at the coastline of Nambangan Surabaya. They conducted reading Sholawat Burdah at the strait of Madura (Beritabaru.co, 17 April2020). The secretary of PW GP Ansor Jatim, A. Ghufron Siradj stated that the reading of sholawat burdah was an effort in order that the spread of Covid-19 ends soon. In doing the shalawat, they were following the covid19 protocol as stipulated by the government. The reading / chanting shalawat burdah was not done by walking around the village, instead it was done at the boats at the sea. For two hours they moved at the strait by incessantly reading shalawat burdah. This activity brought a psychological impact for Surabaya people and surrounding. In this context, reading the shalawat burdah has been a psychological shield to be submissive to God, and not frustrated amidst the pandemic.

\section{Conclusion}

From the discussion, it can be concluded that Burdah keliling was a highly meaningful activity for the people that committed the 'shalawatan'. The pandemic Covid-19, for the rural community, become a very stressful time. In one side people did not know what to do, and on the other side, there were so many warnings that restricted their lives and their way of making a living. They could not get food to eat if they stop working at the field or market. The depressing situation makes people confused and depressed. 
The practice of Burdah keliling is one of the important social cultural approach in dealing with the depressing situation of pandemic Covid-19. The discussion above strengthen the notion that local culture of burdah keliling contributes to the psychological wellbeing of the community in dealing with the depression of the pandemic covid-19. People's resilience was strengthened through the activity that is still communal in action, but they are aware with the situation that it is pandemic and the threat of the virus covid-19.

The submissiveness to Allah SWT importantly contributes to people's resilience in facing the pandemic. People are able to be notified many other aspects of the pandemic or the virus, through the communication in the "forum" of the burdah keliling. In short, Burdah keliling has become a symbolic communication in responding to the depressing situation in pandemic and postpandemic.

\section{About the Author/S}

Dr. Mundi Rahayu, M.Hum is a senior lecturer on cultural studies and Literary studies at English Literature Department, Faculty of Humanities, Universitas Islam Negeri (UIN) Maulana Malik Ibrahim Malang. She got her doctorate degree in Cultural and Media Studies, Gadjah Mada University, Yogyakarta, in 2015. Her research interest ranges from the topics of literary studies, cultural and media studies interconnected with Islamic studies. Her research in the last five years cover the themes of Women in literature and film, Literacy for young people, religion in the new media, and religion in popular movies. She publishes some of her work in national accredited journals and international journals. She can be reached at mundirahayu@gmail.com or mundi@bsi.uin-malang.ac.id.

Mediyansyah, M.I.kom is the lecturer of journalism at Faculty of Humanities UIN Maulana Malik Ibrahim malang. He graduated from the Communication studies of Universitas Sebelas Maret Surakarta. His research interests range the communication studies, media and cultural studies. $\mathrm{He}$ can be reached at mediansyahtaharani@yahoo.co.id

\section{References}

[1] Abdullah, I. 2020. "Covid-19 dan Pengetahuan Budaya yang Diabaikan" (dalam Suwignyo, 2020) Pengetahuan Budaya dalam Khasanah Wabah. UGM Press.

[2] Adib, Muhammad. 2009. Burdah Antara Kasidah, Mistis Dan Sejarah. Yogjakarta: Pustaka Pesantren.

[3] Dhofier, Zamakhsyari. 1982. Tradisi Pesantren, Studi tentang Hidup Kyai. Jakarta:LP3ES.

[4] Fairclough, Norman. 1989. Language and Power. United Kingdom: Longman Group UK Ltd.

[5] Glasse, Cyril. 1996. Ensiklopedi Islam.Terjemahan dari The Concise Encyclopaedia ofIslam. Jakarta: PT Raja Grafindo Persada

[6] Grant. Aimee. 2019. Doing Excellent Social Research with Documents; Practical Examples and Guidance for Qualitative Researchers. Routledge.

[7] Hikam, AS. 1996. "Bahasa Dan Politik: Penghampiran Discursive Practice”, in Yudi Latif Dan Idi Subandy, 1996, Bahasa Dan Kekuasaan: Politik Wacana Di Panggung Orde Baru. Bandung: Mizan.

[8] Hitti, Philip K. 2005. History of The Arabs: From the Earliest Times to the Present (Diterjemahkan oleh Cecep Lukman Yasin dan Dedi Slamet Riyadi). Jakarta: P.T. Serambi Ilmu Semesta.

[9] Manshur, Fadlil M. 2006. Resepsi Kasidah Burdah Al-Bûshîry Dalam Masyarakat Pesantren. Humaniora. Vol. 18, No. 2

[10] Setiawan, Eko. 2015. Nilai-Nilai Religius dalam Syair Shalawat Burdah. LiNGUA Vol. 10, No. 1, Juni 2015

[11] Storey, John. 1993. The Introduction to Cultural Theories and Popular Culture. Simon \& Schusster International Group.

[12] Van Dijk, Teun. 2008. Discourse and Context; A Socio Cognitive Approach. UK: Oxford University Press.

\section{Online News}

[13] "Tangkal Virus Corona, Warga Jelgung Baca Sholawat Burdah Kelilingi Desa." JatimPos.Co. 31 Maret 2020 
[14] "Mengetuk Pintu Langit, Ansor Jatim Baca Sholawat Burdah di Tengah Laut." Beritabaru.co. 17/04/2020

[15] "Baca Burdah keliling kampung,cara warga Situbondo tangkal COVID-19". Antara Jatim.19 Maret 2020

[16] Youtube: Burdah Keliling di Desa Prajjan, Calong, Sampang

[17] Kompas.com. Update berita Covid-19 